\title{
Expanding the dairy herd in pasture-based systems: The role for sexed semen use on virgin heifers
}

\author{
I. A. Hutchinson, ${ }^{1}$ L. Shalloo, and S. T. Butler \\ Teagasc, Animal and Grassland Research and Innovation Centre, Moorepark, Fermoy, Co. Cork, Ireland
}

\begin{abstract}
A model was developed to examine the effects of sexed semen use on replacement heifer numbers and rate of herd expansion in a seasonal dairy production system. Three separate herds were established according to the type of semen used on virgin heifers: conventional frozen-thawed (Conv), sexed fresh (SFre), or sexed frozen-thawed (SFro). In the model, sexed semen was used for the first and second inseminations in heifers only. Pregnancy rates achieved with sexed fresh and sexed frozen-thawed semen were assumed to be $94 \%$ and $75 \%$ of those achieved with conventional frozen-thawed semen, respectively. Initial herd size was 100 cows, which was maintained for the first $2 \mathrm{yr}$ of the 15-yr simulation, after which all available replacement heifers were retained to facilitate herd expansion. Two different scenarios of land availability (S1 and S2) were examined for each of the 3 herds using different semen types: land available allowed expansion to a maximum herd size of 150 cows (S1) or 300 cows (S2). Once maximum herd size was reached, sexed semen use was discontinued and all excess heifer calves were sold at 1 mo of age. All capital expenditure associated with expansion was financed with a 15-yr loan. Each of the different options was evaluated in terms of annual farm profit, annual cash flow, and total discounted net profit. The analysis was completed at a milk price of $€ 0.27 / \mathrm{L}$, and sensitivity around milk price was carried out at $€ 0.22 / \mathrm{L}$ and $€ 0.32 / \mathrm{L}$. The use of SFre generated more replacement heifers and thus faster herd expansion compared with SFro and Conv semen. Maximum herd size was reached in yr 5, 6, and 7 under $\mathrm{S} 1$, and in yr 10, 12, and 14 under S2 for SFre, SFro, and Conv herds, respectively. Total discounted net profit under S1 for the SFre herd was $€ 19,929$ greater than that of the SFro herd and $€ 41,852$ greater than that of the Conv herd. Under S2, discounted net profit for the SFre herd was $€ 138,587$ greater than that of the SFro herd and $€ 239,987$ greater than that of the Conv herd.
\end{abstract}

Received September 5, 2012.

Accepted October 16, 2012.

${ }^{1}$ Corresponding author: ian.hutchinson@teagasc.ie
All 3 herds suffered negative cash flows for extended periods under both S1 and S2 at the lower milk price of $€ 0.22 / \mathrm{L}$, although cash flows were most negative in the SFre herd. The use of sexed semen, in particular fresh sexed semen, in dairy heifers facilitates faster and more profitable expansion compared with the use of conventional frozen-thawed semen. Financial pressures caused by low milk price were greatest when the rate of expansion was highest.

Key words: sexed semen, herd expansion, economics, simulation model

\section{INTRODUCTION}

The ability to increase the numbers of dairy heifer calves born in a herd by selecting the sex of offspring at conception is of great benefit to dairy industries around the world. Flow cytometry was identified as a reliable method to distinguish populations of $\mathrm{X}$ - and $\mathrm{Y}$ chromosome-bearing sperm over 30 yr ago (Garner et al., 1983). Numerous refinements to the procedure have taken place to facilitate the commercial application of this technology (Garner and Seidel, 2008; Sharpe and Evans, 2009), which consistently produces a sex bias of approximately $90 \%$ in resulting offspring. To date, however, low sorting speeds and poor harvest rates of sorted sperm have dictated that commercial application of this technology is only possible with much lower doses of sperm per insemination compared with conventional semen (Garner and Seidel, 2008).

The combined effects of low sperm dose per insemination and reductions in sperm quality and viability due to damage during the sorting process result in reduced pregnancy rates per AI compared with conventional semen (Seidel et al., 1999). The majority of research has therefore focused on the use of sexed semen in virgin heifers to capitalize on their inherently higher fertility compared with lactating cows (Garner and Seidel, 2008). Data from several studies using virgin heifers indicate that pregnancy per AI with frozen-thawed sexed semen is approximately 70 to $80 \%$ of that with conventional semen (DeJarnette et al., 2009, 2010; Chebel et al., 2010). Preliminary results from New Zealand indicate that using fresh sexed semen results in conception rates 
that are 90 to $95 \%$ of those achieved with conventional frozen-thawed semen in lactating cows (R. Vishwanath, LIC, Hamilton, New Zealand, personal communication). Avoiding the sperm damage and losses associated with the freeze-thaw process clearly has beneficial implications for fertility performance (Watson, 1995). The relative importance of fertility is greater in seasonal, pasture-based dairy systems such as in Ireland than in nonseasonal systems (Veerkamp et al., 2002). High pregnancy rates within a short period following the start of mating are required to achieve a compact calving period in early spring, which in turn is necessary to maximize pasture utilization and profitability (Dillon et al., 1995).

The impending abolition of the European Union milk quota regimen in 2015, coupled with an ambitious target set by the Irish government in the Food Harvest 2020 report for a $50 \%$ increase in milk output by 2020 (DAFF, 2010), presents a real opportunity for Irish dairy farmers to increase milk output and herd size for the first time in more than $30 \mathrm{yr}$. The use of sexed semen to generate increased numbers of replacement dairy heifers could accelerate the increase in herd size at both the individual and national herd levels. In the long term, availability of suitable land to increase milk production will represent a major barrier to profitable expansion in Ireland. In the short term, however, dairy farms are operating at relatively low stocking rates (1.8 livestock units per ha; O'Donnell et al., 2008), indicating that initial expansion efforts should focus on increasing the number of lactating cows on the existing grazing platform.

The objective of this paper was to describe and evaluate a model for the use of sexed semen in virgin heifers in Irish dairy herds. The effect of using 3 different types of semen product (fresh sexed semen, frozen-thawed sexed semen, and frozen-thawed conventional semen) on herd expansion and farm profitability were investigated under 2 different scenarios of land availability.

\section{MATERIALS AND METHODS}

\section{Fertility Model}

A model was developed using Microsoft Excel (Microsoft Corp., Redmond, WA) to simulate the reproductive performance of a spring-calving dairy herd over a 15-yr period. The effect of using sexed semen (either fresh or frozen-thawed) or conventional semen in virgin heifers on the number of heifers available for incorporation into the lactating herd was compared.

In the model, 3 separate herds were established according to the type of semen used in virgin heifers: conventional frozen-thawed (Conv), sexed fresh (SFre), or sexed frozen-thawed (SFro). In all herds, AI was used only for the first 2 inseminations, after which all cows and heifers were bred to natural service. In the Conv herd, conventional frozen-thawed semen was used for all inseminations on heifers and lactating cows during the period of AI use. In the SFre herd, sexed fresh semen was used for the first and second inseminations in heifers only, and lactating cows were inseminated with conventional frozen-thawed semen during the period of AI use. Similarly, in the SFro herd, sexed frozen-thawed semen was used for the first and second inseminations in heifers only, and lactating cows were inseminated with conventional frozen-thawed semen during the period of AI use. Therefore, the only difference in AI use was based on the first 2 inseminations in heifers only.

\section{Reproductive Performance of Heifers}

The submission rates (SR; proportion of heifers intended to be bred that were inseminated within a 3 -wk period) and conception rates (CR; proportion of heifers conceiving to a given insemination) used in the model for heifer reproductive performance are summarized in Table 1. The differences in CR between conventional and sexed (either fresh or frozen) semen are in line with the most up to date information available internationally (Chebel et al., 2010; DeJarnette et al., 2010; R. Vishwanath, LIC, Hamilton, New Zealand, personal communication). In the analysis, we assumed that sexed semen was used only for the first and second inseminations in heifers. A difference in CR between the 3 semen types for third and fourth inseminations was implemented to reflect the greater proportions of otherwise fertile heifers that were not pregnant after the first and second inseminations in the sexed semen treatments compared with the conventional semen treatment (i.e., result of the semen product used).

The model was based on a 12-wk breeding season, with breeding commencing on April 25 every year. For the purposes of the model, the breeding season was split into four 3 -wk periods, and calculations were performed on the proportion of heifers not pregnant at the start of each of the four 3-wk periods using the SR and $\mathrm{CR}$ values shown in Table 1. Heifers were inseminated following spontaneous estrus; use of synchronization for the first insemination was not included in the model. All heifers that did not conceive in a given 3 -wk period were eligible for insemination in the next 3 -wk period. The heifers that conceived were attributed a conception date that was the median date of that 3 -wk period. The mean calving date for the following year was then calculated as the mean conception date $+282 \mathrm{~d}$. All heifers that conceived were included in the model for the lactating herd of their respective treatments (con- 
Table 1. Reproductive performance of heifers in the model, using either conventional frozen-thawed, sexed fresh, or sexed frozen-thawed semen

\begin{tabular}{lccc}
\hline & \multicolumn{3}{c}{ Semen type } \\
\cline { 2 - 4 } & $\begin{array}{c}\text { Conventional } \\
\text { frozen-thawed }\end{array}$ & $\begin{array}{c}\text { Sexed } \\
\text { fresh }\end{array}$ & $\begin{array}{c}\text { Sexed } \\
\text { frozen-thawed }\end{array}$ \\
\hline First and second insemination & 0.90 & 0.90 & 0.90 \\
$\quad$ Submission rate & 0.70 & 0.66 & 0.53 \\
Conception rate & 0.75 & 0.75 & 0.75 \\
Third and fourth insemination & 0.30 & 0.35 & 0.45 \\
Submission rate & Conception rate & & \\
\hline
\end{tabular}

${ }^{1}$ Submission rate $=$ proportion of heifers intended to be bred that are inseminated within a 21-d period; conception rate $=$ proportion of heifers pregnant to a given insemination .

ventional frozen-thawed, sexed fresh, or sexed frozenthawed) the following year.

The model assumed that all replacement heifers had reached puberty and were eligible for breeding by approximately 14 to 16 mo of age, and subsequently calved for the first time at approximately 23 to $25 \mathrm{mo}$ of age. Only heifers born within the first 6 wk of the calving period were retained as dairy replacements.

\section{Reproductive Performance of Lactating Cows}

As only conventional semen was used for inseminations in lactating cows, the reproductive performance of the lactating herd was maintained at the same level for the $15-y r$ period of the simulation. Submission rates, conception rates, and embryo survival rates vary according to the cow's DIM during the breeding season. The values used for SR, CR, and embryo survival are shown in Table 2 . These values were derived from large field studies in pasture-based systems that indicated poorer reproductive performance in cows with short intervals from calving to planned start of mating (Herlihy et al., 2011; MacMillan, 2012).

The model was based on a 12 -wk breeding season, with breeding commencing on April 25 every year. In seasonal-calving production systems, there is no minimum voluntary waiting period. Any cow showing signs of estrus once the breeding season has started is inseminated, regardless of days since calving. Any cows that had not conceived by the end of the 12-wk period were culled from the herd. For the purpose of the model, the breeding season was split into four 3 -wk periods, and all calculations were performed on a herd basis. Days in milk at each stage of the breeding season was calculated from calving date until the first day of each 3 -wk period. The values for SR, CR, and embryo survival (Table 2) were applied at the herd level to the proportion of cows not pregnant in each of the four 3 -wk periods during the breeding season. All cows that did not conceive in a given 3 -wk period were eligible for insemination in the next 3-wk period. Mean calving dates were calculated using the same method outlined in the heifer reproductive performance model. This mean calving date was then used in the model for the following year to calculate DIM at the date of planned breeding.

The number of cows that underwent embryo loss was calculated as a proportion of the cows that conceived in each 3 -wk period and varied according to DIM at insemination. When embryo loss occurred, these cows were not eligible for re-insemination until $6 \mathrm{wk}$ after the initial successful insemination. Cows were not reinseminated if embryo loss occurred after the end of the 12-wk breeding season.

\section{Mortality and Survival}

Mortality in the lactating herd was assumed to be $2 \%$, and voluntary culling in the lactating herd was assumed to be $8 \%$ of the cows that remained in the herd following involuntary culling. These figures were applied to each herd at year-end for every year of the simulation.

Heifer calf survival to 1 mo of age was assumed to be $96 \%$ of successful conceptions (DAFF, 2012), and heifer calf survival to breeding at approximately 14 mo of age was assumed to be $96 \%$ of successful calf survival beyond 1 mo of age (DAFF, 2012).

Table 2. Reproductive performance of lactating cows in the model ${ }^{1}$

\begin{tabular}{lccc}
\hline $\begin{array}{l}\text { DIM at } \\
\text { insemination }\end{array}$ & $\begin{array}{c}\text { Submission } \\
\text { rate }\end{array}$ & $\begin{array}{c}\text { Conception } \\
\text { rate }\end{array}$ & $\begin{array}{c}\text { Embryo } \\
\text { survival }\end{array}$ \\
\hline$>83$ & 0.90 & 0.60 & 0.98 \\
$63-83$ & 0.85 & 0.55 & 0.95 \\
$42-62$ & 0.78 & 0.48 & 0.93 \\
$21-41$ & 0.67 & 0.37 & 0.91 \\
$<21$ & 0.20 & 0.20 & 0.90 \\
\hline
\end{tabular}

${ }^{1}$ Submission rate $=$ proportion of cows intended to be bred that are inseminated within a 21-d period; conception rate $=$ proportion of cows pregnant to a given insemination. 


\section{Semen Costs}

Semen costs were established by surveying the main cattle breeding companies in Ireland and reflect current market prices. The price of a straw of conventional frozen-thawed semen from a dairy sire was set at $€ 21$, and the price of a straw of sexed fresh or frozen-thawed semen from a dairy sire was set at $€ 47$. It was assumed that all inseminations were carried out by AI technicians. An insemination fee of $€ 16$ per cow for the first service was allocated in each of the herds; there was no insemination fee for repeat heats, in accordance with current practice in the cattle breeding industry in Ireland.

\section{Milk Production}

Milk production per cow was dependent on parity, and full yield potential was reached at fourth lactation. Milk production was $0.75,0.92$, and 0.98 of fourth lactation yield for first, second, and third parity cows, respectively, calculated using historical Irish milk production data (Central Statistics Office, 2012). Milk production per cow increased by $1 \% / \mathrm{yr}$, from a starting point of $5,750 \mathrm{~kg} /$ cow per year for fourth-lactation animals in yr 1 of the simulation. Milk constituents also increased annually, with milk fat content increasing by $0.5 \% / \mathrm{yr}$ and milk protein content increasing by $0.3 \% /$ yr, from a starting point of a fat content of $39.3 \mathrm{~g} / \mathrm{kg}$ and protein content of $33.9 \mathrm{~g} / \mathrm{kg}$ in the first year of the simulation. The increased levels of milk and milk constituent production represent the annual rate of gain in genetic potential for milk production and were calculated using historical Irish milk production data (Central Statistics Office, 2012).

\section{Financing Expansion}

The investment required to finance herd expansion is outlined in Table 3. In all herds, we assumed that the farm had adequate facilities for the 100 cows on the farm in yr 1 and 2 of the simulation. A figure of $€ 1,500$ per cow was attributed to all herds in yr 1 of the simulation to represent the cost of facilities currently in place on the farm. Thereafter, we assumed that for every 1-cow increase in herd size up to 150 cows there was an investment in facilities of $€ 3,000$, and over 150 cows we assumed that the investment required would be $€ 2,000$ per cow. This difference was included to reflect the nonlinear investment costs associated with expansion and that there is an increased cost associated with lower levels of expansion. The investment was financed with a 15-yr loan and depreciated over a 15 -yr period. To account for the fact that investment
Table 3. Investment required $(€)$ to fund herd expansion in 2 different scenarios of land availability, in which land available limits maximum herd size to 150 cows (scenario 1) or to 300 cows (scenario 2)

\begin{tabular}{lcc}
\hline & \multicolumn{2}{c}{ Investment required $(€)$} \\
\cline { 2 - 3 } Semen type & Scenario 1 & Scenario 2 \\
\hline Conventional & 300,000 & 317,200 \\
Year 1 & - & 282,800 \\
Year 7 & 300,000 & 410,600 \\
Sexed-fresh & - & 189,400 \\
Year 1 & 300,000 & 360,000 \\
Year 7 & - & 240,000 \\
Sexed-frozen & & \\
Year 1 & & \\
Year 7 & & \\
\hline
\end{tabular}

happens in stages on a farm, all investment required up to yr 7 was carried out in yr 1 , and that required between yr 7 and 15 was carried out in yr 7 .

\section{Scenarios}

Two different scenarios of land availability were examined for each of the 3 herds using different semen types. Scenario 1 (S1) limited the land available for expansion to that required for a maximum herd size of 150 cows; herd expansion was limited to a $50 \%$ increase in cow numbers. Heifer calves born on farm within the first 6 wk of the calving period were kept as replacements to expand the herd. Sexed semen was used only until the point at which maximum herd size was reached, after which conventional semen was used for all inseminations. Herd size was maintained at 150 cows, and all excess heifer calves were sold at 1 mo of age. Scenario 2 (S2) limited the land available for expansion to that required for a maximum herd size of 300 cows; herd expansion was limited to a $200 \%$ increase in cow numbers. Heifer calves born on farm within the first 6 wk of the calving period were kept as replacements to expand the herd. Sexed semen was used only until the point at which maximum herd size was reached, after which conventional semen was used for all inseminations. Herd size was maintained at 300 cows, and all excess heifer calves were sold at 1 mo of age.

In both scenarios, the simulation study commenced during the breeding season of spring 2012, with an initial herd size of 100 cows. Herd size was maintained at 100 cows for yr 1 and 2 to reflect the production constraints of the European Union milk quota regimen, which is scheduled to remain in place until 2015.

\section{Economic Analysis}

The Moorepark Dairy Systems Model (MDSM; Shalloo et al., 2004), a stochastic budgetary simulation 
model, was used to simulate a model farm integrating biological data for the different herds generated by each type of semen use under both scenarios of land availability. The model was used to quantify the economic implications of sexed semen use on farm profitability under different expansion capabilities. The key herd default parameters used in the model farm are shown in Table 4. All male and surplus female calves were sold at 1 mo of age. Replacement females were contract reared, leaving the farm at 1 mo of age. We observed a difference in overall pregnancy rate of the heifers under the different semen treatments, which meant that the net cost of replacement heifers to the farm differed with type of semen used. The reduced fertility of fresh and frozen-thawed sexed semen compared with conventional semen increased heifer rearing costs to $€ 1,152$ and $€ 1,180$ for SFre and SFro herds, respectively, compared with $€ 1,145$ for the Conv herd. This was because a greater number of heifers needed to be reared to end up with the same number of heifers calving in the sexed semen options compared with the conventional option.

The default owned farm size was 44.5 ha (Table 4). Land area was treated as an opportunity cost; land was leased out when not required for on-farm feeding of animals in the early years of the simulation, or rented when required due to increased herd size in subsequent years.

The MDSM integrates animal inventory and valuation, milk production, feed requirement, land and labor utilization, and economic analysis. The overall feed requirement was calculated by the MDSM to meet the net energy requirements for maintenance, milk production, and BW change across lactation (Jarrige, 1989) minus energy supplied through concentrate supplementation. Variable costs (fertilizer, contractor charges, medical and veterinarian costs, silage, and reseeding), fixed costs (machinery maintenance and running costs, farm maintenance, car, telephone, electricity, and insurance), and sales values (milk, cull cow, and calf) were based on current prices (Teagasc, 2008). The herds were compared at a milk price of $€ 0.27 / \mathrm{kg}$, assuming $33.0 \mathrm{~g} / \mathrm{kg}$

Table 4. Assumptions used in the model farm

\begin{tabular}{lc}
\hline Item & Value \\
\hline Owned farm size (ha) & 44.5 \\
Reference fat (g/L) & 36 \\
Price ratio protein to fat & 2 \\
Labor costs (€/labor unit) & 22,860 \\
Gross milk price (€/L) & 0.27 \\
Reference cull cow price $(€)$ & 400 \\
Reference male calf price $(€)$ & 75 \\
Reference heifer calf price $(€)$ & 350 \\
Concentrate costs $(€ / \mathrm{t})$ & 220 \\
Opportunity cost of land $(€ /$ ha) & 250 \\
\hline
\end{tabular}

protein and $36.0 \mathrm{~g} / \mathrm{kg}$ fat with a relative price ratio of $1: 2$ for fat:protein.

Annual profit, cash flow, and total discounted profit over the 15-yr period were identified as the key mechanisms in defining the optimum strategy for the different semen options over the 15-yr period. As the different options resulted in different profitability levels over the 15 yr of the investment, the discounted farm profitability allowed a direct comparison between herds, taking into account the different periods of maximum profitability in each of the options. An annual discount rate of $2.5 \%$ was included in this analysis based on historical inflation. Discounted net profit, combined with the value of the inventory change, was used to calculate net worth change over the 15-yr period of the simulation for each herd under S1 and S2. Milk price sensitivity analysis was performed at $€ 0.22 / \mathrm{L}$ and $€ 0.32 / \mathrm{L}$ to examine the financial viability of the 3 herds in both $\mathrm{S} 1$ and $\mathrm{S} 2$ under different milk price assumptions.

\section{RESULTS}

\section{S1: Land Limits Expansion to Maximum 150 Cows}

The key physical outputs from the Conv, SFre, and SFro herds over a 15-yr period are summarized in Figure 1. The SFre herd reached the limit of 150 cows earlier (yr 5) than the SFro (yr 6) and Conv (yr 7) herds. Compared with the SFro and Conv herds, the SFre herd produced more heifer calves in the first $6 \mathrm{wk}$ of the calving season in every year until maximum herd size was reached.

The key financial outputs from the Conv, SFre, and SFro herds over the 15-yr simulation period are summarized in Table 5. Both profit and cash flow were positive for all 3 herds in every year of the simulation. Profit was lowest for all 3 herds in yr 3 of the simulation ( $€ 5,855$, $€ 2,002$, and $€ 2,542$ for Conv, SFre, and SFro herds, respectively), the first year with increased numbers of lactating cows. Thereafter, profit increased annually, reaching a maximum in yr 15 for all 3 herds (€63,048, €63,442, and $€ 63,473$ for Conv, SFre, and SFro, respectively). All 3 herds had reached the 150cow maximum herd size by yr 7 under S1, and required no further investment in facilities in yr 7 . The loans and repayment schedules were therefore the same for the 3 herds, with payments to the bank (capital repayment plus interest) of $€ 30,888 / \mathrm{yr}$, resulting in a total cost of $€ 463,315$ for each herd.

\section{S2: Land Limits Expansion to Maximum 300 Cows}

The key physical outputs from the Conv, SFre, and SFro herds over the 15-yr simulation period are sum- 

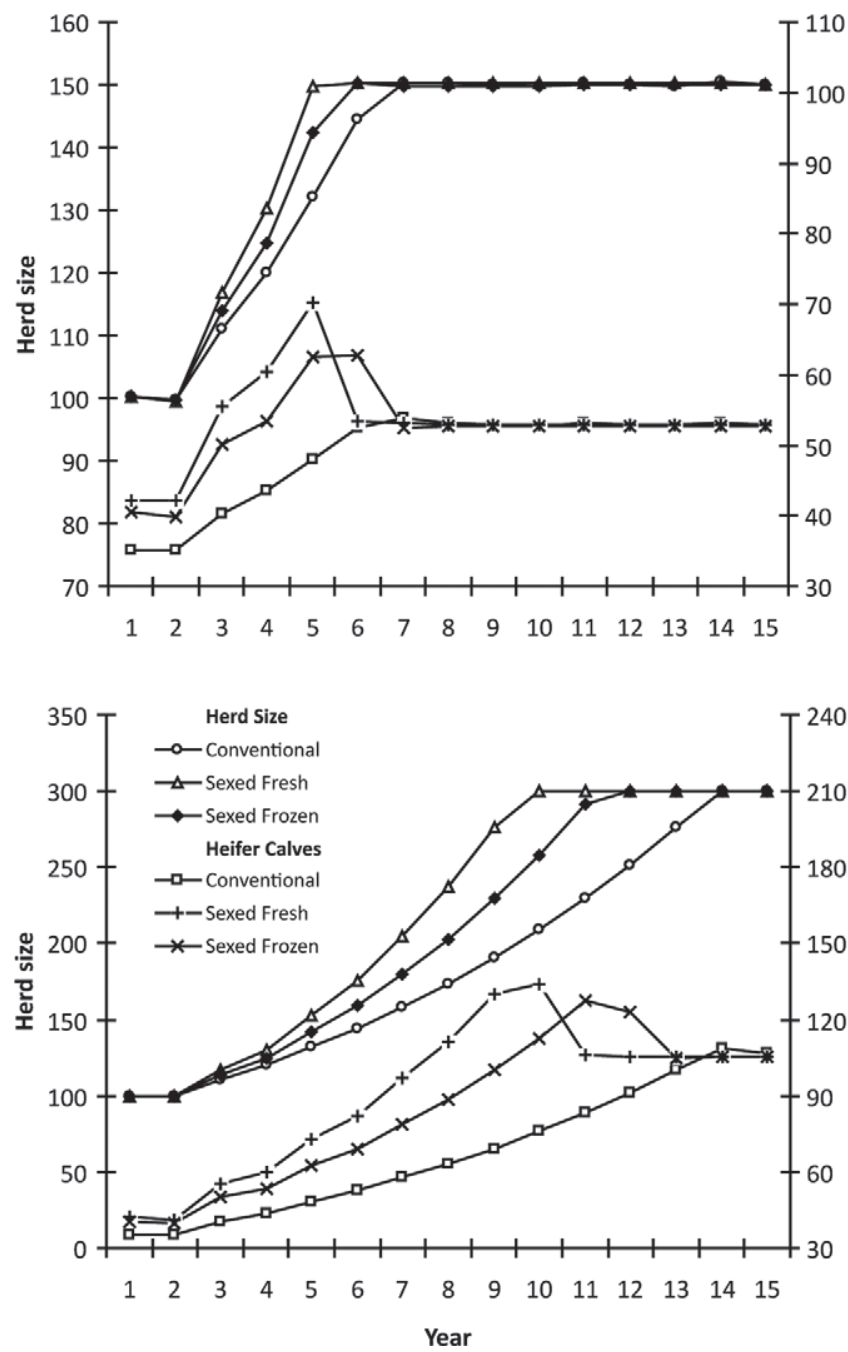

Figure 1. Herd size and number of heifer calves born in the first 6 wk of the calving period surviving to 1 mo of age in herds using sexed fresh semen, sexed frozen-thawed semen, or conventional frozenthawed semen in virgin heifers only, under scenario 1 (upper panel; land available limits maximum herd size to 150 cows) or scenario 2 (lower panel; land available limits maximum herd size to 300 cows).

marized in Figure 1. The SFre herd reached the 300cow limit in yr 10, 2 yr before the SFro herd (yr 12) and 4 yr earlier than the Conv herd (yr 14). Compared with either the SFro or Conv herds, the SFre herd produced more heifer calves in first 6 wk of the calving season in each of the first $10 \mathrm{yr}$ of the model.

The key financial outputs from the Conv, SFre, and SFro herds over the 15-yr simulation period are summarized in Table 6. Profit was negative in yr 1 and 3 of the simulation in the SFre herd, with the most negative profit $(-€ 10,896)$ realized in yr 3 of the simulation and a cumulative profit margin of $-€ 10,676$ over the first 3 yr. Cash flow was also negative in yr 3 in the SFre herd $(-€ 1,267)$. Annual profit and cash flow increased after yr 8 to reach $€ 133,920$ and $€ 104,599$, respectively, in yr 15 of the simulation. The Conv herd maintained positive profit margins for every year of the simulation, but experienced a negative cash flow of $-€ 6,445$ in yr 7 of the simulation. Maximum profit and cash flow were again reached in the final year of the simulation (€127,078 and €100,070, respectively). The SFro herd generated a negative profit margin in yr 3 of the simulation $(-€ 4,455)$, and a negative cash flow in yr 7 (-€5,834). Otherwise, profit margins and cash flow were positive throughout the $15 \mathrm{yr}$ of the simulation, peaking at $€ 124,429$ and $€ 102,361$, respectively, in the final year of the simulation.

The different rates of expansion in the 3 herds resulted in varying loan structures. In the Conv herd, herd size was 159 at yr 7 and 300 at yr 15, resulting in annual repayments (capital plus interest) of €32,601 from yr 1 to 6 , and $€ 73,279$ from yr 7 to 15 . The SFre herd expanded at a faster rate: herd size was 205 at yr 7 and 300 at yr 15. The annual repayments were therefore greater in yr 1 to $6(€ 41,906)$ and lesser in yr 7 to 15 (€69,149), compared with the Conv herd. The SFro herd size was 180 at yr 7 and 300 at yr 15, resulting in annual repayments of $€ 36,865$ from yr 1 to 6 and of $€ 71,387$ from yr 7 to 15 . The capital investment required to fund expansion under S2 was the same in all herds $(€ 600,000)$. The differences in loan structure, however, resulted in variations in interest paid over the 15 -yr simulation period. The total capital and interest cost of expansion was €855,118, €873,782, and €863,671 for Conv, SFre, and SFro herds, respectively.

\section{Net Worth Change}

Net worth change, value of inventory change, and discounted net profit are summarized in Table 7. The value of inventory change was the same for all 3 herds under S1 (€80,305) and the same for all 3 herds under S2 (€326,945). Net worth change was, therefore, directly related to discounted net profit. Under S1, net worth change for the SFre herd was $€ 19,929$ greater than that of the SFro herd and $€ 30,138$ greater than that of the Conv herd. Under S2, net worth change for the SFre herd was $€ 138,587$ greater than that of the SFro herd and $€ 200,332$ greater than that of the Conv herd. Net worth change was greater in all herds under S2 compared with S1.

\section{Milk Price Sensitivity Analysis}

The effects of variations in milk price on cash flow in each of the herds in both scenarios are summarized in Table 8. Cash flow was positive in every year of the simulation for all herds under S1 and S2 at a milk price of $€ 0.32 / \mathrm{L}$. 
Table 5. Financial outputs $(€)$ from 3 herds using conventional frozen-thawed, sexed fresh semen, or sexed frozen-thawed semen in virgin heifers only under scenario 1 , in which land available for expansion limits maximum herd size to 150 cows

\begin{tabular}{|c|c|c|c|c|c|c|c|c|c|}
\hline Year & \multicolumn{3}{|c|}{ Conventional } & \multicolumn{3}{|c|}{ Sexed-fresh } & \multicolumn{3}{|c|}{ Sexed-frozen } \\
\hline 2 & 14,647 & 23,173 & 401,540 & 16,295 & 24,820 & 401,540 & 15,775 & 24,301 & 401,540 \\
\hline 3 & 5,855 & 13,604 & 370,652 & 2,002 & 9,751 & 370,652 & 2,542 & 10,291 & 370,652 \\
\hline 4 & 12,740 & 19,670 & 339,764 & 14,620 & 21,549 & 339,764 & 13,314 & 20,243 & 339,764 \\
\hline 7 & 48,700 & 43,224 & 247,101 & 56,438 & 50,962 & 247,101 & 54,410 & 48,933 & 247,101 \\
\hline 8 & 48,306 & 51,481 & 216,214 & 48,510 & 51,685 & 216,214 & 47,362 & 50,537 & 216,214 \\
\hline 9 & 50,445 & 52,549 & 185,326 & 50,326 & 52,429 & 185,326 & 50,354 & 52,457 & 185,326 \\
\hline 10 & 52,165 & 53,138 & 154,438 & 52,374 & 53,348 & 154,438 & 52,475 & 53,449 & 154,438 \\
\hline 11 & 53,499 & 53,281 & 123,551 & 54,254 & 54,035 & 123,551 & 54,464 & 54,246 & 123,551 \\
\hline 12 & 55,972 & 54,496 & 92,663 & 56.292 & 54,815 & 92,663 & 56.321 & 54,845 & 92,663 \\
\hline 13 & 58,300 & 55,497 & 61,775 & 58,509 & 55,706 & 61,775 & 58,721 & 55,918 & 61,775 \\
\hline
\end{tabular}

${ }^{1}$ Sum of the capital repayments and interest charges owed to the bank at the end of each year.

Under S1, at a milk price of $€ 0.22 / \mathrm{L}$, cash flow was negative in yr 1 to 6 of the simulation for the Conv and SFro herds, and for yr 1 to 5 of the simulation for the SFre herd. Cash flow was most negative in yr 3 for all 3 herds ( $-€ 14,322,-€ 19,407$, and $-€ 18,234$ for Conv, SFre, and SFro herds, respectively).

Under S2, at a milk price of $€ 0.22 / \mathrm{L}$, cash flow was negative in the Conv herd in every year except for yr 15 , negative in the SFre herd in yr 1 to 10 , and negative in the SFro herd in yr 1 to 12 . The most negative cash flow occurred in yr 7 in all 3 herds $(-€ 48,674$, $-€ 53,578$, and $-€ 53,178$ for the Conv, SFre, and SFro herds, respectively).

\section{DISCUSSION}

The current study compared the use of sexed fresh, sexed frozen-thawed, and conventional frozen-thawed semen in virgin heifers in seasonal dairy production systems on several financial performance measures using a bio-economic model. Separate herds were established for each semen type to investigate effects on rate of herd expansion and overall farm profitability.

In Ireland, availability of grazing land around the milking platform is an obstacle to dairy herd expansion. The use of each semen type was therefore considered under 2 scenarios of land availability. Under

Table 6. Financial outputs $(€)$ from 3 herds using conventional frozen-thawed, sexed fresh semen, or sexed frozen-thawed semen in virgin heifers only under scenario 2 , in which land available for expansion limits maximum herd size to 300 cows

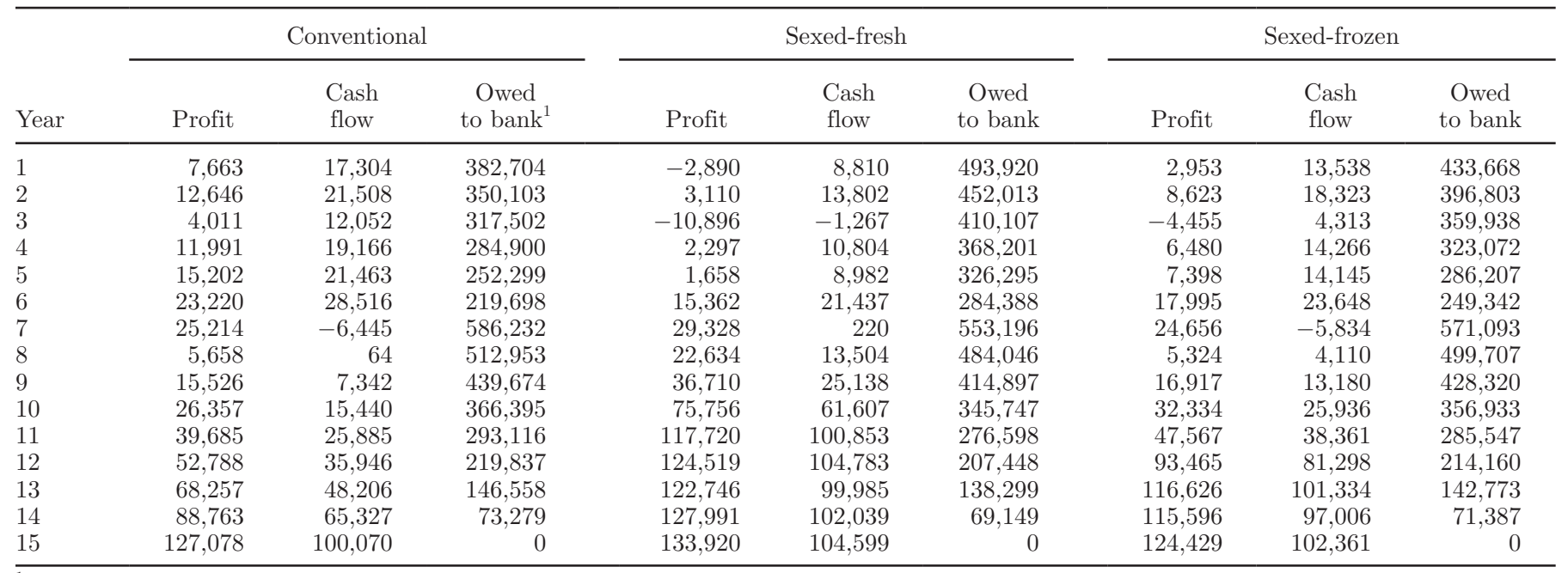

${ }^{1}$ Sum of the capital repayments and interest charges owed to the bank at the end of each year. 
both scenarios, use of sexed fresh semen resulted in the highest level of discounted net profit over the 15-yr simulation compared with using either sexed or conventional frozen-thawed semen. Maximum herd size was also reached earliest in the 15-yr simulation with sexed fresh semen use under both land availability scenarios.

The relative importance of fertility is greater in seasonal systems of dairy production compared with nonseasonal systems (Veerkamp et al., 2002). A compact calving period in late winter or early spring is essential to match the intake demands of the cow to spring pasture growth. High pregnancy rates early in the breeding season are essential if the desired calving pattern is to be achieved. This represents a major barrier to widespread adoption of sexed semen use in seasonal production systems if associated with reductions in conception rates. The current study demonstrates a reduction in farm profit when sexed frozen-thawed semen is used compared with sexed fresh semen. The reduction in farm profit can be directly attributed to the reduction in conception rate in frozen-thawed sexed semen compared with fresh sexed semen (53 vs. 66\%). Reduced fertility was reflected in poorer economic performance through increased rates of culling for infertility, fewer available replacements heifers, increased replacement heifer costs, and increased semen costs. These findings are in agreement with the work of Plaizier et al. (1997).

The negative effects of reduced fertility when using sexed fresh or sexed frozen-thawed semen, compared with conventional semen, were outweighed by the capacity to generate more heifers. This led to faster herd expansion and greater total discounted net profit over the $15 \mathrm{yr}$ of the simulation under different scenarios of land availability. The continuing growth in global demand for dairy products (FAO, 2012) presents dairy farmers around the world with the opportunity to increase milk production. Our results clearly demonstrate the potential role of sexed semen in facilitating the Irish dairy industry's targeted $50 \%$ increase in milk output by 2020 (DAFF, 2010). Use of sexed semen in expansion strategies may be applicable in pastoral dairy systems around the world, although further country-specific analysis is necessary.

Each of the options for semen use under both scenarios were evaluated in terms of farm net profit, cash flow, total discounted farm net profit, and change in net worth. Evaluating the total discounted net profit and change in net worth of each option allows a comparison to be completed that takes into account the varying profit at different stages during the simulation, as the real value of money changes over the 15 -yr period. Although one option may be the best for profitability over the $15 \mathrm{yr}$ of the simulation, the business may become unviable if significant negative cash flows occur at any stage. In the current study, negative cash flows were only an issue under S2 at a milk price of $€ 0.27 / \mathrm{L}$ and under both S1 and S2 at the lower milk price of $€ 0.22 / \mathrm{L}$. Under the European Union's Common Agricultural Policy, farmers in Ireland receive an annual subsidy Single Farm Payment (SFP), which could be used as part of a risk management plan around milk price volatility in the early years of expansion.

The results of the milk price sensitivity analysis demonstrated the difficulties faced by dairy farm businesses at low milk prices. Under S1, at a milk price of $€ 0.22 / \mathrm{L}$, all 3 herds experienced negative cash flows for the first 5 to $6 \mathrm{yr}$ of the simulation. A milk price of $€ 0.22 / \mathrm{L}$ under S2 made all of the herds examined in the current study nonviable. The faster expansion facilitated by sexed semen use exacerbates the severity of negative cash flows, although all 3 herds would struggle to survive even a single year of a low milk price under S2 unless sufficient cash reserves are available. These results strongly support the use of a contingency fund, whereby excess cash from years with higher milk prices may be set aside to provide funding in years of low milk price and support the idea of keeping capital investment to a minimum with expansion. Cash flow budgeting and business planning will have to form a much greater component of dairy farm business in the future to ensure viability is ensured through expansion with volatile milk prices.

Table 7. Discounted net profit, inventory change, and net worth change in herds using conventional frozen-thawed (Conv), sexed fresh semen (SFre), or frozen-thawed sexed semen (SFro) in virgin heifers only, under 2 scenarios of herd expansion, in which land available limits maximum herd size to 150 cows (scenario 1) or to 300 cows (scenario 2)

\begin{tabular}{|c|c|c|c|c|c|c|}
\hline Item & \multicolumn{3}{|c|}{ Scenario 1} & \multicolumn{3}{|c|}{ Scenario 2} \\
\hline Discounted net profit $(€)$ & 458,106 & 488,244 & 468,315 & 403,343 & 603,675 & 465,088 \\
\hline Net worth change $(€)$ & 538,411 & 568,549 & 548,620 & 730,288 & 930,620 & 792,033 \\
\hline
\end{tabular}

${ }^{1}$ The change in value of stock on the farm between yr 1 and yr 15 . 


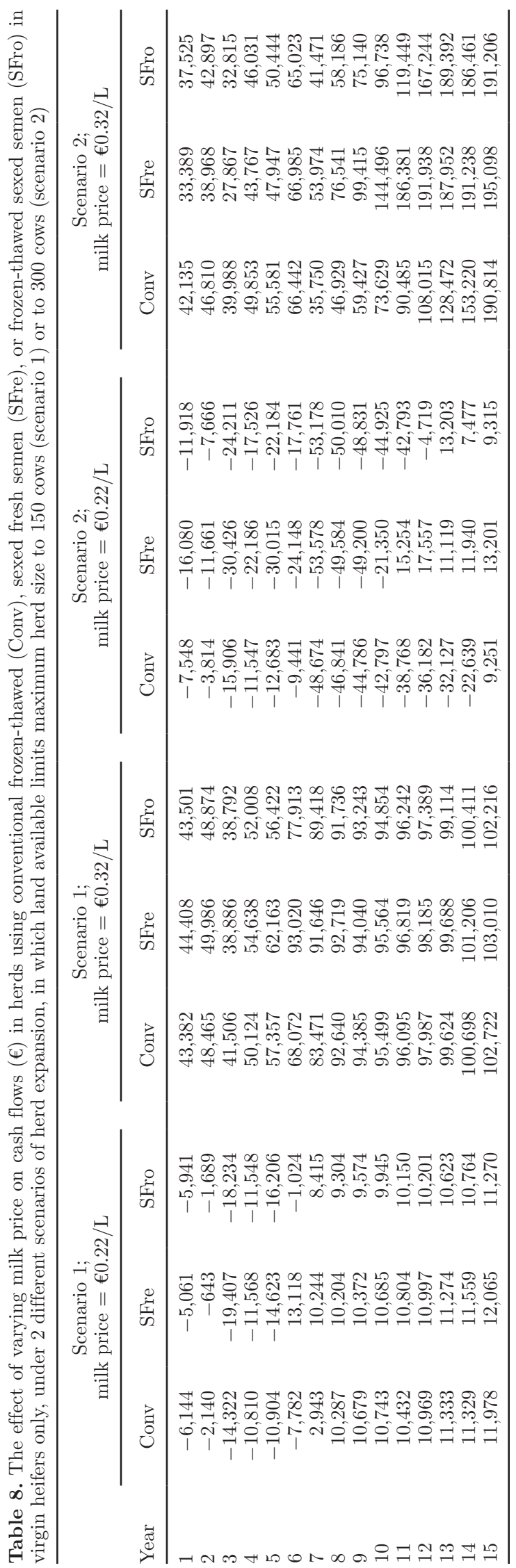

The current study demonstrates the potential benefits of using sexed semen, and in particular fresh sexed semen, in dairy replacement heifers. Several logistical constraints exist, however, in the use of fresh sexed semen. An indigenous AI industry is essential for commercial use of fresh sexed semen because of the requirement for the short interval between semen collection and insemination (24-48 h). In Ireland, approximately $50 \%$ of inseminations carried out in 2012 used semen from Irish bulls (P. Donnellan, Irish Cattle Breeding Federation, Bandon, Ireland, personal communication). In countries where most or all of the semen used is imported from other countries (generally frozen), use of fresh sexed semen is not likely to be feasible.

In seasonal dairy production systems, semen use is restricted to a 3-mo period during late spring and early summer, with peak demand for fresh sexed semen likely to be within a 6 -wk period after the planned start of mating. At present, sorting machines operate at a constant sorting speed all year round, and sorted semen straws are cryopreserved for later distribution. Although semen can be sorted at any period during the year and cryopreserved, frozen-thawed sexed semen is less attractive than fresh sexed semen in seasonal systems because of the reduced conception rate, as shown in this and other studies. In these systems, when the period of AI use is concentrated, sorting capacity will be inadequate to meet demand for fresh sexed semen, at least with current technology. It is worth noting that the demand for fresh sexed semen in pastoral systems would occur at opposite times of the year in countries in the Northern and Southern hemispheres (e.g., Ireland and New Zealand). Relocating multiple sorting machines to follow the seasons, and thereby increasing sorting capacity, may be a viable option to meet the concentrated periods of demand for fresh sexed semen at opposite ends of the globe. Alternatively, new technologies may be developed that have greater sorting speed.

Modeling is the most feasible approach to link variance in reproductive performance to production and profitability (Beukes et al., 2010). It can be used to quickly test alternative breeding strategies or varying levels of reproductive performance that would otherwise require significant financial investment over long periods using traditional experimental approaches. Modeling has been utilized to evaluate the economic consequences of reproductive performance in both seasonal (Beukes et al., 2010) and year-round (Meadows et al., 2005; Inchaisri et al., 2010) dairy production systems. The use of sexed semen and its effects on genetic progress, reproductive performance, and farm net profit have also been investigated using modeling techniques (Ghavi Hossein-Zadeh et al., 2010; Khalajzadeh et al., 2012). 
Previous studies examining use of sexed semen in dairy cattle have suggested that benefits of sexed semen use may include several aspects beyond those considered in the current study. Norman et al. (2010) demonstrated that by increasing the proportion of heifer calves born at the expense of heavier male calves, the incidence of dystocia was reduced in first-calving heifers. Use of sexed semen may therefore reduce dystocia costs in first-calving heifers by up to $20 \%$ (Seidel, 2003). Hohenboken (1999) proposed that sexed semen might be used to accelerate genetic gain in dairy herds by selecting only the highest-ranking cows to breed replacements from with sexed semen. This depends to some extent, however, on the availability of sexed semen from the highest-genetic-merit bulls. Because of the current high level of wastage involved in the sorting process, it is unlikely that sexed semen from such bulls will be available, at least with current sorting technology. It is therefore questionable whether sexed semen use in Irish dairy production systems will result in any greater genetic gains than are currently attainable with conventional semen use.

Weigel (2004) proposed potential improvements in biosecurity when sexed semen is used to drive herd expansion, as all replacements can be generated on farm, negating the need to buy in stock (and potentially disease) from external sources. Although no animals were purchased in the current study, an important benefit of sexed semen use is the capacity for rapid expansion without buying in live females from external sources.

The financial benefits associated with sexed semen use are very much dependent on the realization of the conception rates assumed in the current study. If sexed semen use results in conception rates inferior to those assumed here, the benefits will very quickly dissipate. The fertility assumptions used in this study were taken from studies conducted in the United States and New Zealand. Field studies conducted in Ireland would be necessary to verify the expected conception rates with the sexed semen products under Irish conditions. Further work is required to determine the effect of extending sexed semen use to include lactating cows.

\section{CONCLUSIONS}

The current study demonstrates a beneficial role for the use of sexed semen in virgin heifers to profitably support dairy herd expansion in seasonal, pasturebased dairy systems, such as those in Ireland. Greater profit margins can be attained using either fresh or frozen-thawed sexed semen compared with conventional semen. These profit margins are attained despite the slight reduction in fertility with the sexed semen products. Use of sexed semen will, however, reduce cash flows during the expansion phase and may not be economically viable at a low milk price.

\section{REFERENCES}

Beukes, P. C., C. R. Burke, G. Levy, and R. M. Tiddy. 2010. Using a whole farm model to determine the impacts of mating management on the profitability of pasture-based dairy farms. Anim. Reprod. Sci. 121:46-54.

Central Statistics Office (CSO). 2012. Milk production data. Accessed Jun. 5, 2012. http://www.cso.ie/px/pxeirestat/database/eirestat/ Agriculture\%20Milk\%20Production/Agriculture\%20Milk\%20Production_statbank.asp.

Chebel, R. C., F. S. Guagnini, J. E. P. Santos, J. P. Fetrow, and J. R. Lima. 2010. Sex-sorted semen for dairy heifers: Effects on reproductive and lactational performances. J. Dairy Sci. 93:2496-2507.

DAFF (Department of Agriculture, Food and Fisheries). 2010. Food Harvest 2020: A vision for Irish agri-food and fisheries. Accessed Jun. 8, 2012. http://www.agriculture.gov.ie/media/migration/ agri-foodindustry/foodharvest2020/2020FoodHarvestEng240810. pdf.

DAFF (Department of Agriculture, Food and Fisheries). 2012. AIM Bovine Statistics Report 2011. Accessed Jul. 19, 2012. http:// www.agriculture.gov.ie/media/migration/animalhealthwelfare/ animalidentificationandmovement/AimBovineStats090512.pdf.

DeJarnette, J. M., C. R. McCleary, M. A. Leach, J. F. Moreno, R. L. Nebel, and C. E. Marshall. 2010. Effects of 2.1 and $3.5 \times 10^{6}$ sex-sorted sperm dosages on conception rates of Holstein cows and heifers. J. Dairy Sci. 93:4079-4085.

DeJarnette, J. M., R. L. Nebel, and C. E. Marshall. 2009. Evaluating the success of sex-sorted semen in US dairy herds from on farm records. Theriogenology 71:49-58.

Dillon, P., S. Crosse, G. Stakelum, and F. Flynn. 1995. The effect of calving date and stocking rate on the performance of springcalving dairy cows. Grass Forage Sci. 50:286-299.

FAO (Food and Agriculture Organisation). 2012. Milk availability: Trends in production and demand and medium-term outlook. Accessed Jun. 12, 2012. http://www.fao.org/docrep/015/an450e/ an450e00.pdf.

Garner, D. L., B. L. Gledhill, D. Pinkel, S. Lake, D. Stephenson, M. A. Van Dilla, and L. A. Johnson. 1983. Quantification of the X- and Y-chromosome-bearing spermatozoa of domestic animals by flow cytometry. Biol. Reprod. 28:312-321.

Garner, D. L., and G. E. Seidel Jr. 2008. History of commercializing sexed semen for cattle. Theriogenology 69:886-895.

Ghavi Hossein-Zadeh, N., A. Nejati-Javaremi, S. R. Miraei-Ashtiani, and H. Kohram. 2010. Bio-economic evaluation of the use of sexed semen at different conception rates and herd sizes in Holstein populations. Anim. Reprod. Sci. 121:17-23.

Herlihy, M. M., D. P. Berry, M. A. Crowe, M. G. Diskin, and S. T. Butler. 2011. Evaluation of protocols to synchronize estrus and ovulation in seasonal calving pasture-based dairy production systems. J. Dairy Sci. 94:4488-4501.

Hohenboken, W. D. 1999. Applications of sexed semen in cattle production. Theriogenology 52:1421-1433.

Inchaisri, C., R. Jorritsma, P. L. A. M. Vos, G. C. van der Weijden, and H. Hogeveen. 2010. Economic consequences of reproductive performance in dairy cattle. Theriogenology 74:835-846.

Jarrige, J. 1989. INRAtion v. 2.7: Microsoft computer program of ration formulation for ruminant livestock. J. Agabriel, P. Champciaux, and C. Espinasse, ed. Cnerta, Dijon, France.

Khalajzadeh, S., A. Nejati-Javaremi, and H. M. Yeganeh. 2012. Effect of widespread and limited use of sexed semen on genetic progress and reproductive performance of dairy cows. Animal 6:1398-1406.

MacMillan, K. 2012. The InCalf Project: Improving reproductive performance of cows in Australian dairy herds. Pages 6-18 in Dairy Cow Fertility - Reproductive Performance for Efficient PastureBased Systems. http://www.teagasc.ie/publications/2012/1162/ Dairy_Cow_Fertility_Proceedings_2012.pdf.

Meadows, C., P. J. Rajala-Schultz, and G. S. Frazer. 2005. A spreadsheet-based model demonstrating the nonuniform economic effects 
of varying reproductive performance in Ohio dairy herds. J. Dairy Sci. 88:1244-1254.

Norman, H. D., J. L. Hutchison, and R. H. Miller. 2010. Use of sexed semen and its effect on conception rate, calf sex, dystocia, and stillbirth of Holsteins in the United States. J. Dairy Sci. 93:38803890.

O'Donnell, S., L. Shalloo, A. M. Butler, and B. Horan. 2008. A survey analysis of opportunities and limitations of irish dairy farmers. J. Farm Manage. 13:419-434.

Plaizier, J. C. B., G. J. King, J. C. M. Dekkers, and K. Lissemore. 1997. Estimation of economic values of indices for reproductive performance in dairy herds using computer simulation. J. Dairy Sci. 80:2775-2783.

Seidel, G. E., Jr. 2003. Economics of selecting for sex: The most important genetic trait. Theriogenology 59:585-598.

Seidel, G. E., Jr., J. L. Schenk, L. A. Herickhoff, S. P. Doyle, Z. Brink, R. D. Green, and D. G. Cran. 1999. Insemination of heifers with sexed sperm. Theriogenology 52:1407-1420.
Shalloo, L., P. Dillon, M. Rath, and M. Wallace. 2004. Description and validation of the Moorepark Dairy System Model. J. Dairy Sci. 87:1945-1959.

Sharpe, J. C., and K. M. Evans. 2009. Advances in flow cytometry for sperm sexing. Theriogenology 71:4-10.

Teagasc. 2008. Management Data for Farm Planning. Teagasc, Oakpark, Carlow, Ireland.

Veerkamp, R. F., P. Dillon, E. Kelly, A. R. Cromie, and A. F. Groen. 2002. Dairy cattle breeding objectives combining yield, survival and calving interval for pasture-based systems in Ireland under different milk quota scenarios. Livest. Prod. Sci. 76:137-151.

Watson, P. F. 1995. Recent developments and concepts in the cryopreservation of spermatozoa and the assessment of their postthawing function. Reprod. Fertil. Dev. 7:871-891.

Weigel, K. A. 2004. Exploring the role of sexed semen in dairy production systems. J. Dairy Sci. 87(E. Suppl.):E120-E130. 